\title{
Introduction
}

This issue features several articles that focus on private higher education. Privatization is one of the slogans of the 1990s, and it is a trend worldwide in higher education. The first two articles here discuss the role of research institutes in Latin America, and private initiatives in Azerbaijan. A third article, on Russia, also deals in part with privatization trends. Not only are new private institutions being established worldwide, but public universities are being partially privatized by making them responsible for an increasing share of their budgets. British higher education, for example, has slowly been privatized over the past decade. The implications for access, equity, basic research, traditional ideas of autonomy, and academic freedom of these trends have hardly been examined. Privatization may be inevitable, but it also deserves critical analysis and debate.

Philip G. Altbach

\section{Private Research Centers: Changing the Face of Latin American Higher Education and Development}

\section{Daniel C. Levy}

Daniel Levy is professor of educational administration and policy studies, Latin American studies, and political science, University at Albany. Address: ED 315, SUNY Albany NY 12222. Fax 518 442-5084; email: DCL05@cnsibm.albany.edu. *This article is based on Levy's Building the Third Sector: Latin America's Private Research Centers and Nonprofit Development, University of Pittsburgh Press, 1996.

$\mathrm{S}$ cholarly works and policy discussions on higher education systems too often overlook institutions that do not claim to combine teaching and research. They give particularly little attention to institutions that focus on research and do little or no teaching. Yet such research institutions are a major and rising presence in much of the world.

One root of neglect relates to faith in the research university as the ideal type of higher education institution. The faith, often enshrined in a nation's legislation or in assistance programs by international agencies, is misplaced: the model makes sense for certain higher education circumstances and goals, but not all. In any case, this higher education form is rare, both today and historically, especially if one leaves aside the pretenders: places that claim to do research but do not (at least by any acceptable standards). Even in the United States and Germany, von Humboldt notwithstanding, the research university is only one historical form and today shares the research terrain with private industry, public research centers, and private think tanks.

In Latin America an extraordinary breakthrough in research has been concentrated outside the university. Private research centers (PRCs) have led a revolutionary surge in social and policy research. PRCs are juridically private and freestanding institutions that do not distribute profits. They usually rank high in nongovernment finance and governance. Alongside PRCs, and covering other research fields, lie a panoply of kindred international centers, public centers, centers structurally tied to larger private organizations, and centers located within universities but outside the faculties that dominate teaching.

\section{In Latin America an extraordinary breakthrough in research has been con- centrated outside the university. Private research centers have led a revolution- ary surge in social and policy research.}

Generally best known by their acronyms (e.g., Brazil's IUPERJ, Chile's CIEPLAN, Peru's GRADE), PRCs are often more skilled, prolific, and influential than their public university counterparts. They hold a disproportional share of the best credentials and talent, including the leading intellectuals. Beyond picking up the slack for faltering public institutions, PRCs spearhead a surge in the quantity, quality, and relevance of the region's social research. And while most PRCs do not engage in graduate education, those that do are atypically large and often provide the best quality available.

PRCs also epitomize how research institutions can be far more than academic institutions. In socioeconomic terms, PRCs are instrumental in designing and promoting 
development alternatives to official policies and, in other situations, in designing the official policies themselves. Some PRCs directly serve many business organizations. Many make a vital contribution in knowledge, training, information, and studies for booming nonprofit grassroots organizations, helping to build the Third Sector (nonprofit) and thereby provide development options not restricted to just the public and for-profit private sectors; in fact, many nonprofits are simultaneously PRCs and social action institutions. In their policy activities PRCs often function politically as think tanks. Furthermore, PRCs' net political impact is decidedly democratic, both in opposition to authoritarian regimes and in collaboration with their successors. Many PRCs assume a leadership role that intellectuals and university students have traditionally played in Latin America: a claim on national consciousness and identity.

The substantial success of PRCs contrasts with the emphasis on failure that characterizes much literature on comparative higher education, Third World research productivity, and philanthropy. The positive evaluation emerges as the analysis of PRCs ranges across issues of their definitional boundaries, the reasons for their growth and adaptability, the sources of finance and the control that may accompany that finance, the macropolitical questions related to PRCs under different regimes, and micropolitical questions related to intraorganizational governance. Success is qualified, however, by the fragility and dependence of most PRCs and by a series of academic weaknesses. PRCs are not adequate substitutes for good research universities; in some ways they even become obstacles to their development.

PRCs do not lead in every nation, much less in every aspect of social research, but a four-part categorization shows only two nations where PRCs clearly have less weight than universities in social research. The main categories are where the research is: (1) plentiful and mostly, or almost exclusively, packed into PRCs, (2) more limited yet impressively expanded and, again, packed mostly into PRCs, (3) developed in major part by both PRCs and universities. Attention to PRCs is attention to a vital part of higher education and provides new perspectives on the universities to which research centers have formed such attractive alternatives.

\section{The Emergence of Private Postsecondary Education in the Former Soviet Republic of Azerbaijan}

\section{James S. Catterall and Raymond McGhee, Jr}

James S. Catterall is professor and assistant dean, Graduate School of Education and Information Studies, University of California at Los Angeles. Raymond McGhee Jr. is an ESL teaching specialist with interests in the Middle East and an advanced doctoral student in comparative education and sociology of education at UCLA. This article is based on "The Emergence of Private Postsecondary Education in the Former Soviet Republics: A Case Study from the Caspian," a paper presented at the annual meeting of the American Educational Research Association, New York, April 1996. Available from Prof. James S. Catterall, Department of Education, University of California, Los Angeles, 405 Hilgard Ave. Los Angeles, CA 90095-1521.

7 he collapse of the former Soviet Union has propelled 1 its former republics along tortuous paths toward selfdetermination. Outside of Russia, less visible sagas are unfolding on the periphery in the Transcaucasian region and the Central Asian republics lying east of the Caspian Sea. These newborn national systems and their people face challenges that can only be called daunting. Their Soviet-developed institutions of higher learning presently lack support for basic operations and are literally crumbling apart. Moreover, the very values and orientations their citizens will need to succeed in a world free-market economy have been systematically denied and denounced over about four generations of Soviet control. So a change toward a Western and market orientation to the world, the sine qua non of economic advancement and even survival in the reasoning of most observers, represents a monumental undertaking-it calls for a reordering at the mindset level. This abstract, drawn from a longer work recently completed by the authors, presents a description of the conditions of change in the higher education system in the former Soviet republic of Azerbaijan, and the emergence of private postsecondary institutions in the present period of social transformation.

\section{Higher Education in Azerbaijan}

The system of higher education in Azerbaijan was a part of a massive system established by the former Soviet Union. The system was characterized by tremendous differentiation in types and missions of institutions. Higher education institutions were centrally financed and controlled 